\title{
Émotions et régulation émotionnelle en contexte sportif interpersonnel ou intergroupe
}

L'étude du processus émotionnel a pendant longtemps été dominée par des recherches mobilisant une approche intra-individuelle, regroupant, par exemple, une myriade d'études sur la relation émotions-performance, ou bien encore les stratégies de coping. En comparaison, beaucoup moins de connaissances existent à l'heure actuelle concernant la compréhension des liens entretenus entre les variables caractérisant la dynamique de groupe et le processus émotionnel (Campo, Mackie, \& Sanchez, 2019). Ce manque de connaissances implique des confusions sémantiques, voire parfois paradigmatiques, qui nuisent à l'acception globale de ce qu'est l'essence même du processus émotionnel : un processus psychosocial (Lazarus 1991, 1999 : Mackie et al., 2000).

Considérer ainsi l'influence d'autrui sur les émotions et leur régulation offre donc de nouvelles perspectives d'investigation et de compréhension du vécu des pratiquants sportifs, que ce soit dans le champ de la performance, de l'éducation physique ou encore des activités physiques adaptées et de la santé (Campo \& Louvet, 2016). Récemment, ces questionnements ont fait l'objet d'un engouement scientifique sans précédent dans le domaine de la psychologie du sport avec des concepts novateurs émergeants, tels que la régulation émotionnelle interpersonnelle et le communal coping (Campo et al., 2017; Friesen et al., 2013; Tamminen \& Gaudreau, 2014; Tamminen et al., 2016), les émotions de groupe (Campo et al., 2018, 2019a, 2019b, in press; Tamminen et al., 2016), et l'approche hybride de l'intelligence émotionnelle (Lane et al., 2009; Laborde et al., 2016).

L'objectif de ce numéro spécial est d'alimenter ces nouveaux questionnements. Nous espérons ainsi inciter la communauté scientifique travaillant dans le champ des émotions en sport à dépasser les analyses classiques et les conceptions idiographiques, pour davantage s'inscrire dans une approche psychosociale des émotions et du processus émotionnel.

Ce numéro spécial débute par une sélection d'articles investissant le champ de la valence interpersonnelle des compétences de régulation émotionnelle, pris au sens large. Le premier article de Lane, Friesen, Stanley et Devonport (Université de Wolverhampton, RoyaumeUni) examine la différence entre les états émotionnels vécus par les athlètes et ceux visés par les stratégies de régulation émotionnelle individuelle et interpersonnelle employées en période précompétitive. Le second article de Louvet $^{1}$ et Campo ${ }^{2}$ (Université de Normandie ${ }^{1}$; Université Bourgogne Franche-Comté ${ }^{2}$, France) mobilise le cadre théorique de l'intelligence émotionnelle (IE) dans le corps arbitral, questionnant notamment la valeur discriminante de l'IE eu égard au niveau des arbitres en football. Le troisième article, de Bonk ${ }^{1}$, Leprince ${ }^{2}$ et Doron $^{2,3}$ (Université de Toronto ${ }^{1}$, Canada; INSEP $^{2}$, France; Université de Nantes ${ }^{3}$ ), dresse une revue de littérature sur les rituels collectifs de préparation de match en sports collectifs et met en lien ces pratiques avec les concepts de communal coping et de team resilience. Le quatrième article, de Braun et Tamminen (Université de Toronto, Canada), porte quant à lui sur les interactions entre le coach et les athlètes, éclairées par le cadre théorique de la régulation émotionnelle interpersonnelle.

Deux autres articles mobilisent ensuite la compréhension des vécus émotionnels en sport, notamment au travers de l'approche de l'identité sociale. Le premier de cette seconde partie, de Relave, Campo et Nicolas (Université de Bourgogne Franche-Comté, France) met en évidence par une approche qualitative l'effet de l'entraînement (ici la préparation physique) sur les émotions et la dynamique de groupe. Le second, de Rull et Margas (Université de Caen, France), est une revue de littérature investissant les modèles théoriques issus de la psychologie sociale sur l'influence des menaces sur les attitudes interpersonnelles et intergroupes, en les mettant en relation avec les émotions vécues en contexte sportif.

Ce numéro spécial se termine par un septième article de Cece, Guillet-Descas et Martinent (Université Lyon 1, France) consistant en une revue des méthodes d'analyses longitudinales permettant une modélisation du processus émotionnel prenant en compte l'influence du contexte social.

Ces différents articles mettent en avant une diversité d'approches et d'outils d'analyse pouvant être mobilisés dans le cadre d'une approche psychosociale du processus émotionnel. Au travers de ce numéro spécial, nous espérons ainsi participer à la prise de conscience émergeant dans la littérature actuelle des émotions en sport, sur le 
besoin d'aborder la compréhension du processus émotionnel et de ses effets au travers d'une approche décentrée de l'individu et considérant les influences sociales. Ces connaissances pourront très certainement contribuer à la réalisation de nouvelles études mais aussi être utilisées par les entraîneurs, psychologues ou consultants, ainsi que par les sportifs pour aborder de manière innovante la gestion des émotions.

Nous adressons nos plus vifs remerciements aux auteurs et aux experts pour leur investissement dans ce numéro rédigé essentiellement en langue anglaise. Bien que non exhaustif, il offre une première illustration de l'étendue, et de la complexité passionnante de cette nouvelle approche des émotions en sport.

\section{Emotions and emotion regulation in interpersonal and intergroup sport contexts}

Emotional process in sport has been mainly studied through an intra-individual approach, including, for example, a myriad of research on the relationship between emotions and performance, or coping strategies. In comparison, much less knowledge exists about the influence of psychosocial variable on emotions and emotion regulation (Campo, Mackie, \& Sanchez, 2019). This lack of knowledge implies semantic, sometimes even paradigmatic confusions, which undermine the overall meaning of what is the essence of the emotional process: a psychosocial process (Lazarus 1991, 1999: Mackie et al., 2000).

Therefore, considering the influence of others offers new perspectives in the field of emotions in sport performance, physical education or exercise (Campo \& Louvet, 2016). Recently, these questions highlighted the academics' interest in the field of sports psychology with emerging innovative concepts, such as interpersonal emotional regulation and communal coping (Campo et al., 2017; Friesen et al., 2013; Tamminen \& Gaudreau, 2014; Tamminen et al., 2016), group emotions (Campo et al., 2018, 2019a, 2019b, in press; Tamminen et al., 2016), and somewhat via that of emotional intelligence (Lane et al., 2009; Laborde et al., 2016).

The purpose of this special issue is to address these new questions. We hope to encourage the scientific community working in the field of emotions in sport to go beyond classical analyzes and idiographic conceptions, so as to be more in line with a psychosocial approach of emotional process.

This special issue begins with a selection of articles investing the field of interpersonal dimension of emotional regulation skills, taken in a broad sense. The first article by Lane, Friesen, Stanley and Devonport (University of Wolverhampton, UK) examines the difference between emotional states actually experienced by athletes, with those targeted by the individual and interpersonal emotional regulation strategies used in the precompetitive period. The second article by Louvet $^{1}$ and Campo ${ }^{2}$ (University of Normandy ${ }^{1}$; University Bourgogne Franche-Comté ${ }^{2}$, France) used the theoretical framework of emotional intelligence (EI) in referees, raising the question of the EI' influence referees' level in soccer. The third article, by Bonk ${ }^{1}$, Leprince ${ }^{2}$ and Doron ${ }^{2,3}$ (University of Toronto $^{1}$, Canada; INSEP ${ }^{2}$, France; University of Nan$\mathrm{tes}^{3}$, France), provides a literature review of the collective game precompetitive routines in team sports, with a specific focus on communal coping and team resilience. The fourth article, by Braun and Tamminen (University of Toronto, Canada), addresses coach-athletes relationships by using the theoretical framework of interpersonal emotional regulation.

Two other articles then investigates the understanding of emotional experiences in sport, particularly through the approach of social identity. Through a qualitative approach, the first paper of this second part, by Relave, Campo and Nicolas (University of Burgundy FrancheComté, France [article in French]) highlights the effect of training (here physical conditioning) on emotions and group dynamics. The second article, by Rull and Margas (University of Caen, France [article in French]), is a review of literature investing theoretical models from social psychology about the influence of threats on interpersonal and intergroup attitudes, by relating them to emotions experienced in a sporting context.

This special issue is finally completed with a seventh article by Cece, Guillet-Descas and Martinent (Lyon 1 University, France) consisting in a review of longitudinal analysis methods allowing to model the emotional process by considering the concomitant effects of contextual variables.

These articles highlight a variety of approaches and methodological tools that can be used as part of a psychosocial approach of the emotional process. Through this special issue, we hope to participate in the emerging awareness that invites academics as well as practitioners to better understand emotional process in sport, as well as its effects, by considering the influence of social processes.

We really thank the authors and experts for their contribution to this issue. Although not exhaustive, this offers a first illustration of the scope, and the fascinating complexity of this new paradigmatic approach of emotions in sport.

Mickaël Campo

Éditeur invité

Laboratoire de psychologie: Psy-DREPI (EA7458), Université Bourgogne Franche Comté, Dijon, France 


\section{Références}

Campo, M., Champely, S., Lacassagne, M.-F., Mackie, D.M., Pellet, J., \& Louvet, B. (in press). Athletes' social identity: its influence on precompetitive group-based emotions. Journal of Sport and Exercise Psychology.

Campo, M., Mackie, D.M., \& Sanchez, X. (2019). Emotions in group sports: a narrative review from a social identity perspective. Frontiers in psychology, 10. https://doi.org/ 10.3389/fpsyg.2019.00666.

Campo, M., Champely, S., Louvet, B., Ferrand, C., Rosnet, E., Pauketat, J., \& Mackie, D.M. (2019). Group-based emotions: evidence for emotion-performance relationships in team sports.

Campo, M., Martinent, G., Pellet, J., Boulanger, J., Louvet, B., \& Nicolas, M. (2018). Emotion-performance relationships in team sport: the role of personal and social identities. International Journal of Sports Science and Coaching.

Campo, M., \& Louvet, B. (2016). Les émotions en sport et en EPS - Enseignement, performance et santé. Bruxelles: Éditions De Boeck.

Campo, M., Sanchez, X., Ferrand, C., Rosnet, E., Friesen, A., \& Lane, A.M. (2017). Interpersonal emotion regulation in team sport: mechanisms and reasons to regulate teammates' emotions examined. International Journal of Sport and Exercise Psychology, 15(4), 1-16.

Friesen, A.P., Devonport, T.J., Sellars, C.N., \& Lane, A.M. (2013). A narrative account of decision-making and interpersonal emotion regulation using a social-functional approach to emotions. International Journal of Sport and
Exercise Psychology, 11, 203-214. https://doi.org/10.1080/ 1612197X.2013.773664.

Laborde, S., Dosseville, F., \& Allen, M.S. (2016). Emotional intelligence in sport and exercise: a systematic review. Scandinavian Journal of Science 8 Medicine in Sports, 26, 862-874. https://doi.org/10.1111/sms.12510.

Lane, A.M., Thelwell, R., Lowther, J.P., \& Devonport, T. (2009). Relationships between emotional intelligence and psychological skills among athletes. Social Behaviour and Personality: An International Journal, 37, 195-202. https:// doi.org/10.2224/sbp.2009.37.2.195.

Lazarus, R.S. (1991). Emotion and adaptation. New York, NY: Oxford University Press.

Lazarus, R.S. (1999). Stress and emotion: a new synthesis. New York, NY: Springer.

Mackie, D.M., Devos, T., \& Smith, E.R. (2000). Intergroup emotions: explaining offensive action tendencies in an intergroup context. Journal of Personality and Social Psychology, 79, 602-616. PubMed ID: 11045741. https:// doi.org/10.1037/0022-3514.79.4.602.

Tamminen, K.A., Gaudreau, P. (2014). "Coping, social support, and emotion regulation in teams". In M. Beauchamp, \& M. Eys (Eds.), Group dynamics in exercise and sport psychology: contemporary themes (pp. 222-239), 2nd ed. New York, NY: Routledge.

Tamminen, K.A., Palmateer, T.M., Denton, M., Sabiston, C., Crocker, P.R., Eys, M., et al. (2016). Exploring emotions as social phenomena among Canadian varsity athletes. Psychology of Sports and Exercise, 27, 28-38. https://doi.org/ 10.1016/j.psychsport.2016.07.010.

Citation de l'article : Campo M (2019) Émotions et régulation émotionnelle en contexte sportif interpersonnel ou intergroupe. Mov Sport Sci/Sci Mot, 105, 1-3 